effects. Hydrothermal baroque dolomite is most abundant in porous intervals, and occurs as void-filling cement precipitated in interparticle porosity, fracture porosity, along stylolites, and also as a replacement mineral after anhydrite. During diagenetic dissolution and reprecipitation events, certain elements substitute for $\mathrm{Ca}^{2+}$ in the $\mathrm{CaCO}_{3}$ lattice, in proportion to the composition of the diagenetic fluids. The behavior of substituting cations in this study is largely indicative of diagenesis by subsurface fluids. It also implies that much of the observed diagenetic alteration occurred in a closed diagenetic system. During diagenesis the isotopic content of a carbonate will re-equilibrate with that of surrounding pore fluids. The depletion of $\mathrm{O}^{18}$ implies precipitation at elevated temperatures or from subsurface fluids, while $\mathrm{C}^{13}$ consistency reflects original carbon composition. Values from this study coincide with those for other Jurassic carbonates and late dolomites. Petrography and geochemistry indicate that diagenesis occurred in the marine phreatic, mixed phreatic, meteoric phreatic, and subsurface diagenetic environments.

SUTER, JOHN R, Louisiana State Univ., Baton Rouge, LA, and AMY K. MAYNARD, Exxon Co. USA, Houston, TX

\section{Regional Variability of Washover Deposits on South Texas Coast}

Overwash processes play an important role in determining the stratigraphy of microtidal barrier islands. Along the microtidal coast of south Texas, regional variability in barrier island geometry produces a spectrum of washover types. South Padre Island is a low profile, transgressive feature with a discontinuous to nonexistent foredune ridge. It displays sheet overwash, coalescing washover terraces, and washover fans fed by large hurricane channels. North Padre and Mustang Islands are high-profile barrier islands with continuous foredune ridges, and thus only small, discrete interdune washovers occur. The relict tidal inlets between Mustang and Padre Islands are the sites of the largest washovers in the system, termed reactivated tidal deltas. This last type, although relatively rare in modern washover deposits, is probably similar in mode of origin to the large lobate back barrier features found on many high profile barriers on the Texas coast.

Internal structures of the washovers were studied by trenching, box coring, and vibracoring. The dominant stratification type is plane beds with extensive heavy mineral laminae. Washover margins display some landward dipping foreset bedding. Hurricane channels show cut and fill structures with shell lags, plane beds, and some trough cross-beds. Directional features indicate that the washovers are formed by storm surge flood, and modified by surge ebb. This is supported by the existence of separate flanking ebb channels on some washovers, as well as current velocity simulations for the storm surge of Hurricane Allen, which show that flood currents are both stronger and longer lived than the ebb.

In the ancient record, low profile barriers should be relatively thin deposits consisting of numerous coalescing washovers. Thicker sand bodies corresponding to high profile barriers should be found along strike. Since back-barrier facies have a higher preservation potential than other barrier environments, such a deposit might be dominated by reactivated tidal deltas.

THOMAS, WILLIAM A., and STEPHEN H. WOMACK, Univ. Alabama, Tuscaloosa, AL

\section{Coal Stratigraphy of Deeper Part of Black Warrior Basin in Alabama}

The Warrior coal field of Alabama is stratigraphically in the upper part of the Lower Pennsylvanian Pottsville Formation and structurally in the eastern part of the Black Warrior foreland basin. In the Warrior coal field, the Pottsville Formation has been divided into a lower non-coalproductive sandstone-rich sequence and an upper coal-productive sequence that contains less sandstone. The productive coal beds extend southwestward from the mining area downdip into the deeper part of the Black Warrior structural basin. Because the deep part of the basin is beyond the limits of conventional coal exploration, study of the stratigraphy of coal beds must rely on data from petroleum wells. For example, the density log as run in petroleum wells is sensitive to the presence of coal beds more than a few inches thick, but evidently does not provide a reliable measure of the thickness of individual coal beds. Relative abundance of coal can be stated in terms of numbers of beds, but because of the limitations of the available data, thicknesses of coals presently are not accu- rately determined. Distribution of coal beds in the Black Warrior basin reflects controls by depositional environments from delta plain to barrier islands; the various depositional environments shifted across the Black Warrior basin through time.

The lower sandstone-rich coal-poor part of the Pottsville has been interpreted as barrier sediments in the mining area. To the southwest in the deeper Black Warrior basin, coal beds are more numerous within the sandstone-dominated sequence. The area of most numerous coals, trends northwestward parallel with the trend of the barrier islands, and evidently is in a back-barrier location.

The coal-productive upper Pottsville is informally divided into "coal groups" (in ascending order, Black Creek, Mary Lee, Pratt, Cobb, Gwin, Utley, and Brookwood), each of which includes several coal beds. The Black Creek, Mary Lee, and Utley coal groups are associated with northeast-trending delta-distributary sandstones. The areas of most numerous coals also trend northeastward and are laterally adjacent to relatively thick distributary sandstones, suggesting coal accumulation in backswamp environments. The most numerous coals in the Pratt coal group are in an area that trends northwestward parallel with and southwest of a northwest-trending linear sandstone, suggesting coal accumulation in a back-barrier environment. Equivalents of the Cobb, Gwin, and Brookwood coal groups contain little coal in the deep part of the Black Warrior basin.

\section{TURNER, JAMES R., Pruet Oil Co., Shreveport, LA}

Problematical Petrophysical Characteristics of Smackover at Bayou Middle Fork Field, Claiborne Parish, Louisiana

Values of irreducible water saturation calculated from conventional electric and porosity logs at Bayou Middle Fork field are commonly greater than $60 \%$. Mercury injection curves reveal that the true water saturation averages about $40 \%$. Scanning electron micrographs show oolitic grains that have been recrystallized and have rough irregular surfaces as well as intercrystalline porosity within the particles. Water adheres to these grain surfaces and occupies some of the intercrystalline porosity in productive zones, causing the calculated water saturations to read too high. Application of the Archie equation, the Guillotte et al technique, and the Rocky Mountain technique provides a different suite of water saturations.

Archie water saturations average about $75 \%$ when density-neutron porosity values are used. Density-neutron porosity values tend to read about 2 porosity units low when compared with core porosity values throughout the field. When core corrected porosity is used, the Archie saturation averages about $60 \%$.

The Guillotte et al technique employs a variable textural parameter " $w$ " which is dependent on porosity and permeability. Mean water saturation with this method averages about $49 \%$, which is in better agreement with the mercury injection data.

The Rocky Mountain ratio yields water saturations that are too high until the porosity balance technique is applied. Since $R_{t}$ is assumed to read too low due to the excess immobile water, the Rocky Mountain derived porosities are too low. When $R_{t}$ is increased to balance the porosity the water saturation averages about $43 \%$, using $Z=.025$. When the Rocky Mountain $R_{t}$ is used in the Archic equation, water saturations more consistent with the mercury injection data result. In addition the difference between the observed $R_{t}$ and the Rocky Mountain derived $R_{t_{a}}$ can be plotted as a function of porosity.

\section{VAN SICLEN, C. DEWITT, Univ. Houston, Houston, TX}

\section{Early Mesozoic Tectonics of Northern Gulf of Mexico Coastal Plain}

Major events in the early Mesozoic development of the northern Gulf Coast region are related to corresponding stages in the opening of the central North Atlantic Ocean from its southern end, as interpreted from three prominent lineaments on aeromagnetic maps of the southeastern United States and its offshore region. The Brunswick magnetic anomaly, which marks the edge of continental crust in the Carolina trough, comes ashore in southern Georgia and follows the subsurface belt of Triassic rocks into southwestern Alabama. This belt continues into eastern Texas, occupying a rift system along which North America was then drawing away from South America. 